\title{
DENSITY OF KARST DEPRESSIONS IN YUCATÁN STATE, MEXICO
}

\author{
Yameli Aguilar ${ }^{1,2}$, Francisco Bautista ${ }^{1,3 *}$, Manuel E. Mendoza ${ }^{1}$, Oscar Frausto ${ }^{4}$, and \\ THOMAS IHL ${ }^{1}$
}

\begin{abstract}
The abundance of karst depressions in Yucatán has been widely recognized, but they have not been classified or quantified despite their importance in land-use planning. Our objective was to study the types and areas of the sinkholes, uvalas, and poljes and identify their patterns of spatial distribution. We used 58 topographic maps $(1: 50,000)$ from INEGI, from which we extracted the depressions and bodies of water. For typology, we used a circularity index and the shape and area of the depressions. For single-density analysis, we extracted the centroids and added an inventory of karst features (cenotes, caves). We counted 6717 depressions with a total area of $454 \mathrm{~km}^{2}$ and 750 karst features. We identified 4620 dolines $\left(34 \mathrm{~km}^{2}\right)$, mainly in plateaus below 30 masl. In number, they are followed by uvalas (2021) and poljes (76), occupying together a similar area $\left(210 \mathrm{~km}^{2}\right)$ and dominating in elevations higher than 30 masl. Eighty percent of the dolines were automatically labeled. The density of depressions allowed us to identify the "ring of cenotes" and the "field of dolines" according to two main types of factors, structural and climatic. The typology and density of the depressions could be used as geomorphological differentiation criteria in the vast plateaus of central and eastern parts of the state.
\end{abstract}

\section{INTRODUCTION}

Morphometric studies of the landforms of karstic systems has become very popular since the 1970s (Williams, 1972; White and White, 1979; Gracia, 1987; Gracia-Prieto, 1991; Brinkmann et al., 2008). In the beginning, most of these studies were limited to a set of measurements obtained from field surveys or topographic maps elaborated at large scales (Lyew-Ayee et al., 2007; Bruno et al., 2008; Basso et al., 2013), so that the studied areas were relatively small. In large areas, geomorphological analysis used to be very general (Lugo-Hubp et al., 1992; Lugo-Hubp and Garcia, 1999).

Recent technological developments, such as geographic information systems (GIS), global positioning system (GPS), digital elevation models (DEM), and high resolution satellite images, allow for faster morphometric analysis of landforms and can generate very robust information, increasing our knowledge about the origin and nature of karstic terrain and the factors that have an influence on it (Denizman and Randazo, 2000; Shofner et al., 2001; Hung et al., 2002; Florea, 2005; Lyew-Ayee et al., 2007; Huang, 2007; Gao and Zhou, 2008; Galve et al., 2009; Siart et al., 2009). The implementation of vector-based GIS in karstic studies is still relatively new, but very versatile and increasingly popular (Szukalski, 2002; Gao, 2008; Siart et al., 2009).

Lyew-Ayee et al., (2007), Gao and Zhou (2008), and Ihl et al. (2007) demonstrated the utility of DEM for the morphometric analysis of landforms, mainly in areas with greater landform relief, but the exclusive use of satellite imagery and digital elevation models is insufficient to characterize and automatically detect karstic depressions, mainly dolines and other smaller features (Shofner et al., 2001; GutiérrezSantolalla et al., 2005; Siart et al., 2009; Gutierrez et al., 2014). For this reason, Siart et al., (2009) indicated the need for an alternative approach using a combination of inputs, processing, and spatial analysis, including support and validation by fieldwork.

Several studies have focused on the analysis of the spatial distribution of karstic depressions. Density maps have been among the most common approaches (Denizman, 2003; Angel et al., 2004; Farfán González et al., 2010; Lindsey et al., 2010); there are also some studies on the typology of these landforms, differentiating between dolines, uvalas, and poljes (Plan et al., 2009; Siart et al., 2009; Goeppert et al., 2011; Fragoso-Servón et al., 2014; Pepe and Parise, 2014). These are important in land planning, mainly related to the vulnerability of aquifers to pollution, the risk of ground collapse and subsidence, and potential flooding.

There are previous studies in the Yucatan Peninsula that recognize this diversity of karstic landforms. Cole (1910) and Fich (1965) conducted local studies in some areas of Yucatan and described some examples of the different types of cenotes, the local name for collapse dolines containing water, schematically representing their relationship with the aquifer. Subsequently, other studies about landforms

\footnotetext{
* Corresponding author: leptosol@ciga.unam.mx

${ }^{1}$ Centro de Investigaciones en Geografía Ambiental (CIGA), Universidad Nacional Autónoma de México (UNAM). Antigua Carretera a Pátzcuaro No. 8701, Col. ExHacienda de San José de la Huerta. C.P. 58190. Morelia Michoacán México.

${ }^{2}$ Instituto Nacional de Investigaciones Forestales, Agrícolas y Pecuarias, Centro de Investigación Regional Sureste. Calle 6 No. 398 por 13, Colonia Díaz Ordaz C.P. 97130 Mérida Yucatán México.

${ }^{3}$ Centro de Edafología y Biología Aplicada del Segura, CSIC. Murcia, España.

${ }^{4}$ Universidad de Quintana Roo, Boulevard Bahía s/n colonia del Bosque, Chetumal, C.P. 77019 Quintana Roo, México.
} 


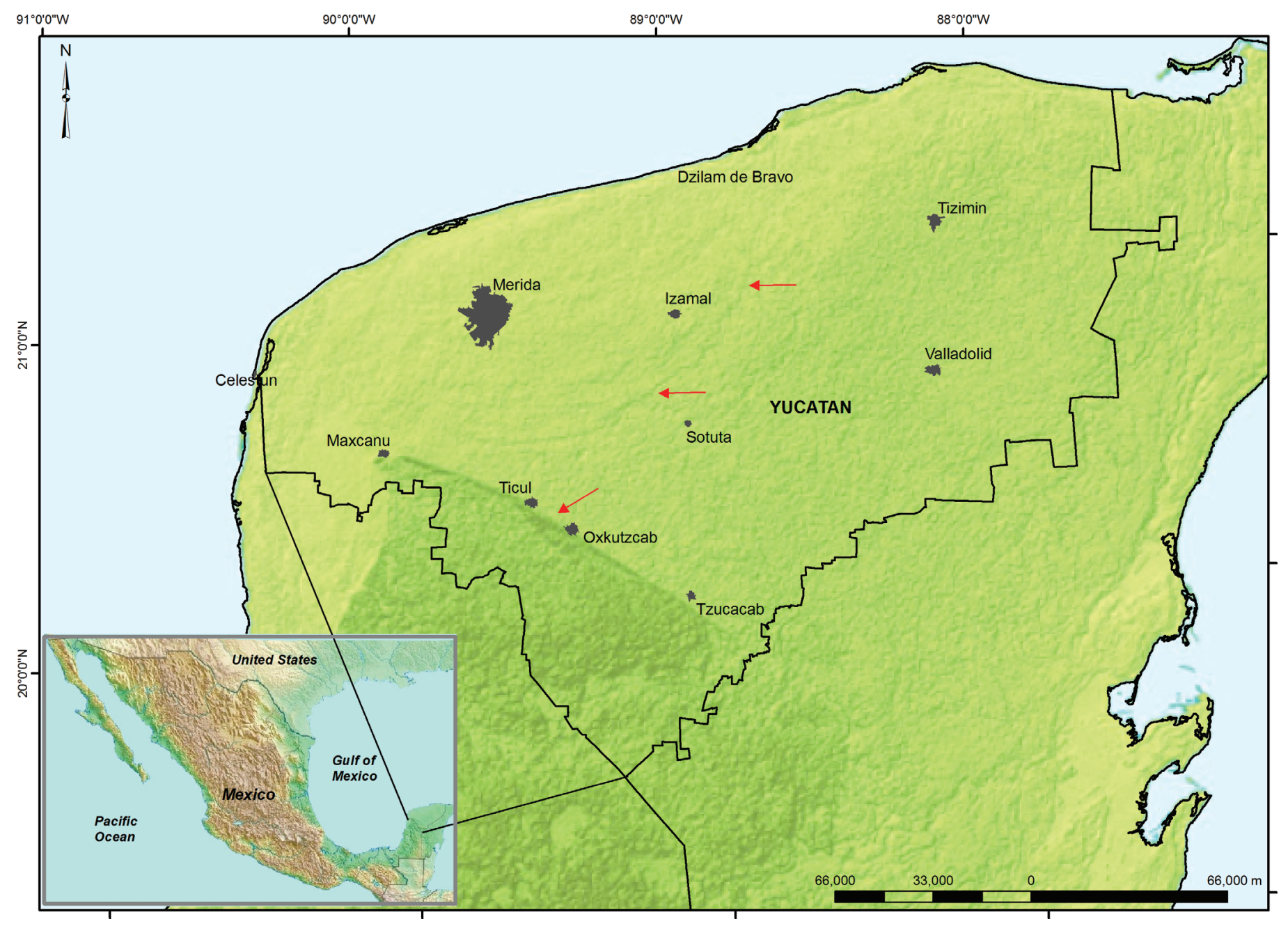

Figure 1. The study area is the state of Yucatán (outlined, modified from NASA/JPL, 2000). Red arrows indicate the ring of cenotes and the aligned hills of Tikul.

of Yucatan were done at small (1:1.2 million; Lugo-Hubp et al., 1992; Lugo-Hubp and Garcia, 1999) and medium scale (1:500,000; Bautista-Zúñiga et al., 2003; Bautista et al., 2005), distinguishing two different geomorphological regions. The first is a large plateau in northeastern Yucatan and the second, in the south, is characterized by a system of plateaus alternating with low hills. Only the south of Yucatan has been described in detail at 1:50,000 scale using DEM and Landsat images (Ihl et al., 2007), but without considering the typology of the different depressions.

Previous studies have recognized that different types of karstic depressions abound in the vast plateaus of the northern and eastern Yucatan Peninsula, named locally as cenotes, aguadas, hondonadas, and rejolladas. However, the quantity, spatial distribution, and characterization of Yucatan depressions have not been sufficiently analyzed on geomorphological maps, despite the great importance of these landforms for proper land management, mainly to protect regional groundwater supplies (Marin-Stillman et al.,
2004). Our objective was to study the types and area of the dolines, uvalas, and poljes and to identify their patterns of spatial distribution in Yucatán state; this basic geomorphological information is needed for better differentiation of the landscape.

\section{Materials AND Methods}

The state of Yucatán has an area of $39,340 \mathrm{~km}^{2}$ and is located in Mexico. The most outstanding structural features of Yucatán are the ring of cenotes and the aligned hills of Ticul (Fig. 1). The hills of Ticul divide Yucatán into two major sub-regions. The north, larger region is where the ring of cenotes is located and continues eastward to where karst plateaus not exceeding $40 \mathrm{~m}$ elevation dominate (Lugo-Hubp et al., 1992; Ihl et al., 2007). The second subregion extends from the aligned hills of Ticul to the south, with topographic elevations higher than $50 \mathrm{~m}$, even reaching $300 \mathrm{~m}$ in some places. There are also extensive systems of 


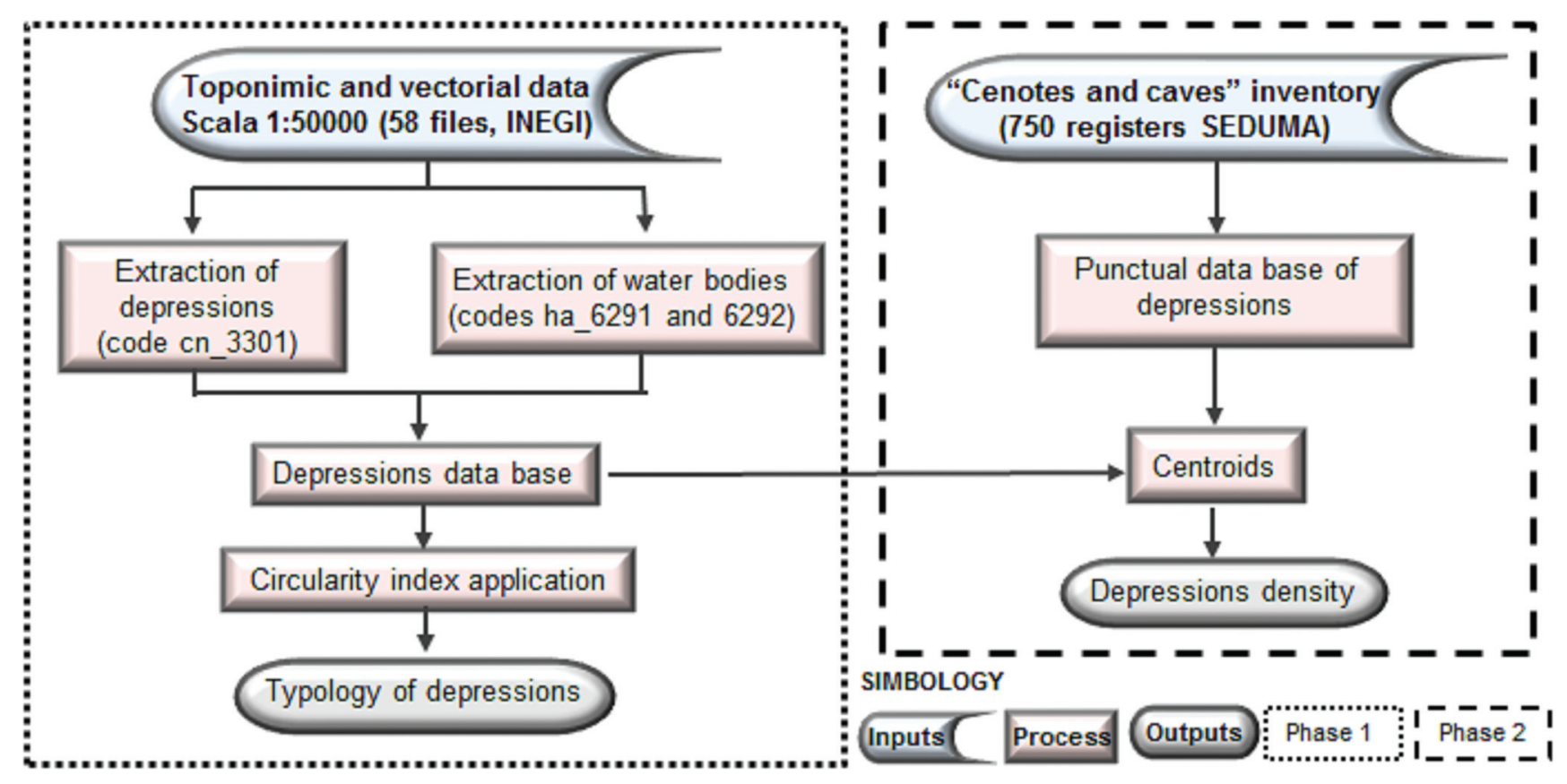

Figure 2. Flow chart of the determination of types of karst depressions and depression density.

caves and caverns in the entire landscape (Finch, 1965; Bonor Villarejo and Sanchez Pinto, 1991).

Climatic subtypes vary from south to north $\left(\mathrm{Aw}_{0}, \mathrm{Aw}_{1}\right.$, $\mathrm{BS}_{0}$, and $\mathrm{BS}_{1}$; García, 2004); the first is warm and humid with summer rains; the second warm and humid with summer and winter rains; the third dry and semi-arid; and the last is the least dry of the semi-arid subtypes. An agroclimatic index called the length of growing period has been applied to the area of study (Delgado-Carranza, 2010; Delgado-Carranza et al., 2011); this index considers the start of the season when precipitation exceeds half the potential evapotranspiration and ends when precipitation is less than half the potential evapotranspiration. The index indicates the number of months, not only of the duration of the rainy season, but also of the amount and intensity of the rain, which have an ascending tendency from the northwest to the southeast. Our calculations (Fig. 2) includes two main phases, the typology of the depressions and their density, which are described below.

\section{Phase 1. Typology of the Depressions}

Our main input was 58 topographic maps at 1:50000 scale, elaborated by the Instituto Nacional de Estadística y Geografía (INEGI, 1999). From these maps, we extracted, in polygon format, the contour lines identified as depressions and the temporary and permanent bodies of water. We assigned a typology to the depressions, differentiating between dolines, uvalas, and poljes. The dolines in the collapsing or collapsing-dissolution region have a shape that resembles a circle, while the uvalas were formed as a result of the coalescence of dolines, and so they have an irregular shape that does not resemble a circle. Finally, poljes have elongated or amorphous shapes with larger area (Pavlopoulos et al., 2009). This was based on an examination of contour lines on the topographic map, which then allowed for calculation the area using ArcGIS 9.3.

To try to automate this typology, we used the Gravelius coefficient $(\mathrm{Gc})$, also called circularity index, given by the formula $\mathrm{Gc}=0.28 \mathrm{P} / \sqrt{\mathrm{A}}$, where $\mathrm{P}$ is the perimeter and $\mathrm{A}$ is the area. The circularity index $\mathrm{Gc}$ is a dimensionless number that provides information about circularity; it is based on the ratio between the perimeter of the object and that of a circle with an equal area. This coefficient will tend to one when the object is most similar to a circle, and will deviate from one when the object has a more irregular shape (Fragoso-Servon et al., 2014, 2015). Polygons with Gc equal to 1 and up to 1.04 were automatically classified as dolines. The classifying criteria for uvalas were an irregular shape and area smaller than $1 \mathrm{~km}^{2}$. The classifying criteria for poljes were an irregular shape and area larger than $1 \mathrm{~km}^{2}$.

All closed contours defined as depressions that fulfill the criterion of Gc equal to 1 and up to 1.04 and that were not reported as water bodies were reclassified as non-flooding dolines. Water bodies were also evaluated using Gc and labeled according to their flooding regime as dolines with temporary flooding and dolines with permanent flooding. There were also uvalas with some kind of flooding regime. The water bodies of the coastal plateau were considered as coastal lagoons, although, according to Delle Rose and Parise (2002), they may also be derived from dolines and uvales.

\section{Phase 2. Density of Depressions}

We extracted the centroids of the polygon in the database generated from information from INEGI (1999) in 


\section{A. Depressions (number)}

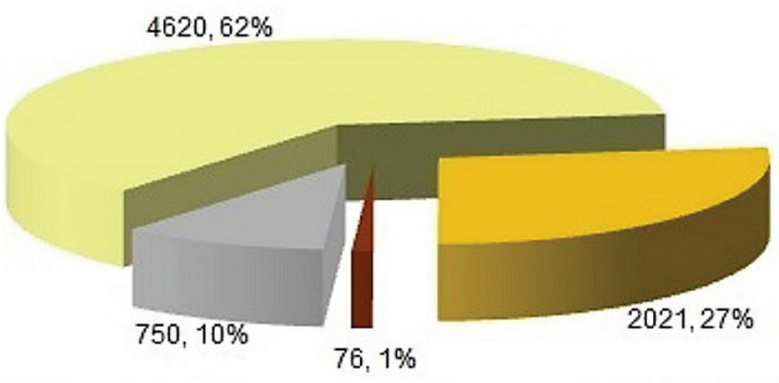

Dolines
Uvalas

Poljes
"Cenotes \& caves" (data point)

\section{B. Depressions (Area km²)}
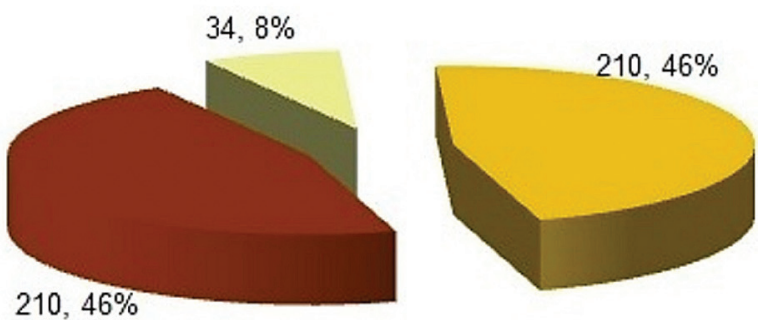

Dolines

Uvalas

Poljes

Figure 3. Numbers (A) and total areas (B) of types of karstic depressions in the study area. The SEDUMA dataset of cenotes and caves does not include areas, so they are not included in part $B$.

Phase 1. This database was complemented with an inventory provided by the Secretaría de Desarrollo Urbano y Medio Ambiente (SEDUMA) of the state of Yucatán that records 750 karst features, mainly cenotes, caves, and grottos; only the name of each location and its geographical coordinates is recorded. It is worth noting that the word cenote is a local term derived from the Mayan $d z o n o t$ or ts'onot used to designate dolines, natural wells, and caves that hold water either permanently or temporarily. Technically, many of these cenotes, those called open-sky cenotes, correspond to typical collapse dolines (Waltham et al., 2005; Gutierrez et al., 2008, 2014). A cave is a natural cavity in rock large enough to be entered by man. It may be water-filled; if it becomes full of ice or sediment and is impenetrable, the term applies but will need qualification. A grotto is a small cave or a room in a cave of moderate dimensions but richly decorated (Jennings, 1997).

To avoid double-counting the bodies of water recorded by INEGI (1999) and by the inventory of cenotes and caves of SEDUMA, a buffer of $25 \mathrm{~m}$ was assigned to each data point recorded by SEDUMA; this buffer corresponded to a length of $1 \mathrm{~mm}$ in the topographic map (1:50000) and was the accuracy of the map; only three coincidences were found. The centroids were used for the single-density analysis, with a search radius of $5 \mathrm{~km}$.

\section{RESULTS}

We counted a total of 6717 karstic depressions, occupying an area of about $454 \mathrm{~km}^{2}$; in addition, we recorded 750 karstic features (cenotes, grottos, and caves). Dolines dominate in quantity (4620); however, they occupy a total of only $34 \mathrm{~km}^{2}$. Poljes and uvalas occupy similar areas of $210 \mathrm{~km}^{2}$, but there is a greater number of uvalas compared to poljes (2021 and 76, respectively; Fig. 3). Specifically, non-flooding dolines are the most numerous (2892) and with the largest total area $\left(25 \mathrm{~km}^{2}\right)$, followed by dolines with permanent flooding and dolines with temporary flooding (Fig. 4).

Using our methods, of the total number of depressions in the area, we identified 4620 as dolines, of which $80 \%, 3699$, were classified automatically by having a circularity index of 1 to 1.04 ; the other $20 \%$ showed slightly higher values (Fig. 5A). The most common circularity index values were 1.02, 1.03, 1.04, and 1.01 (Fig. 5B). The 921 dolines that were not automatically classified were displayed on the computer monitor to verify their geometry and area and

\section{A. Dolines (number)}

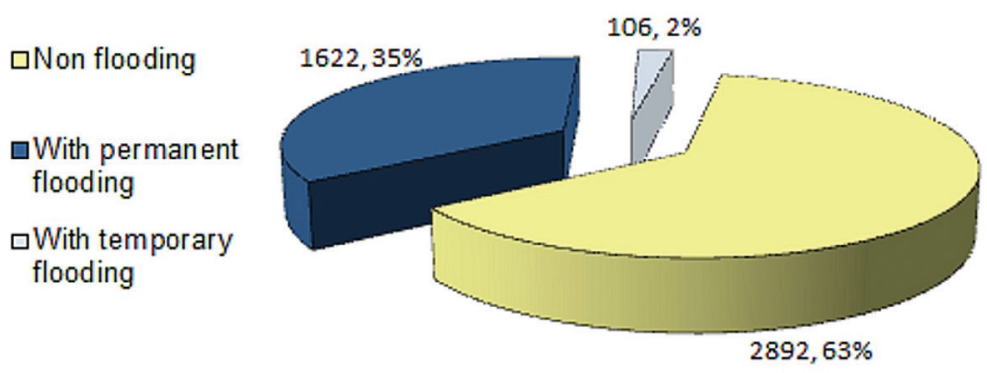

B. Dolines (Area $\mathrm{km}^{2}$ )

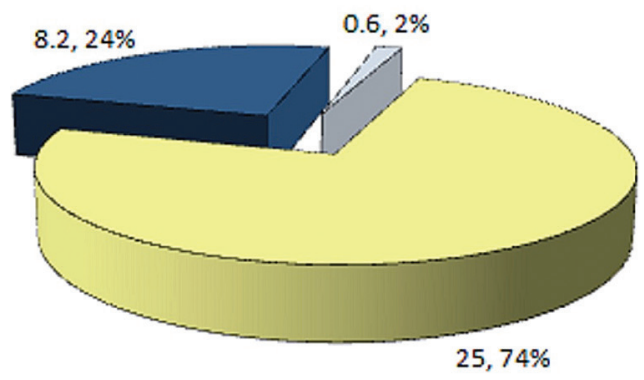

Figure 4. Numbers (A) and total areas (B) of types of dolines found in the study area. 

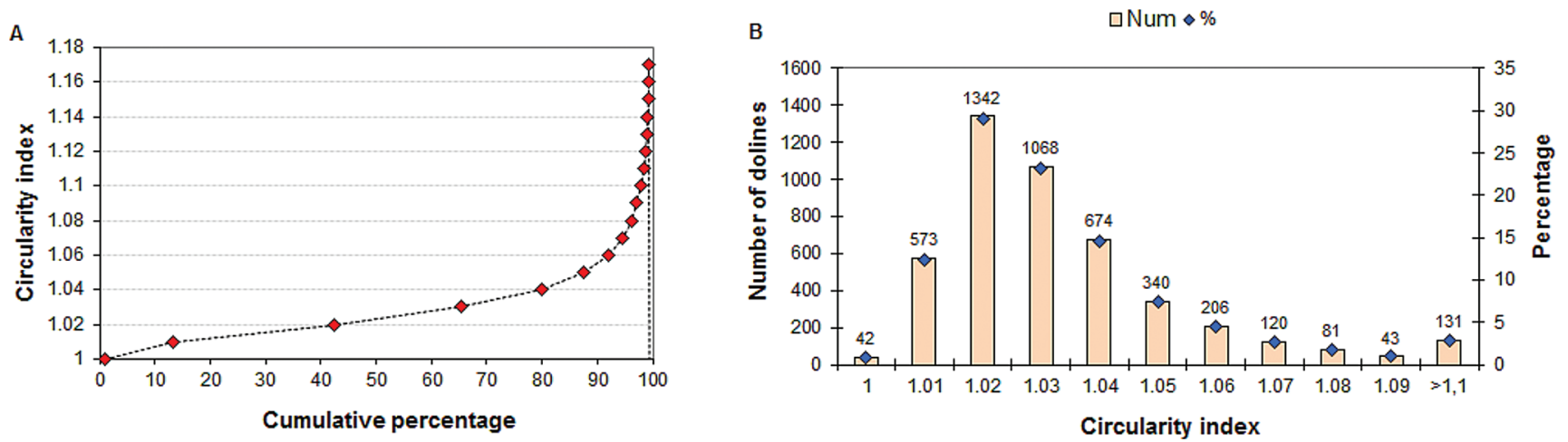

Figure 5. Cumulative plot (A) and frequency distribution by number and percentage (B) of the circularity indexes Gc calculated for the dolines.

were manually labeled. Figure 6 shows the different types of depressions in terms of number (Fig. 6A) and total area (Fig. 6B) differentiated according to elevation intervals from the the digital elevation model.

口dolines auvalas apoljes ם"cenotes \& caves" (data point)
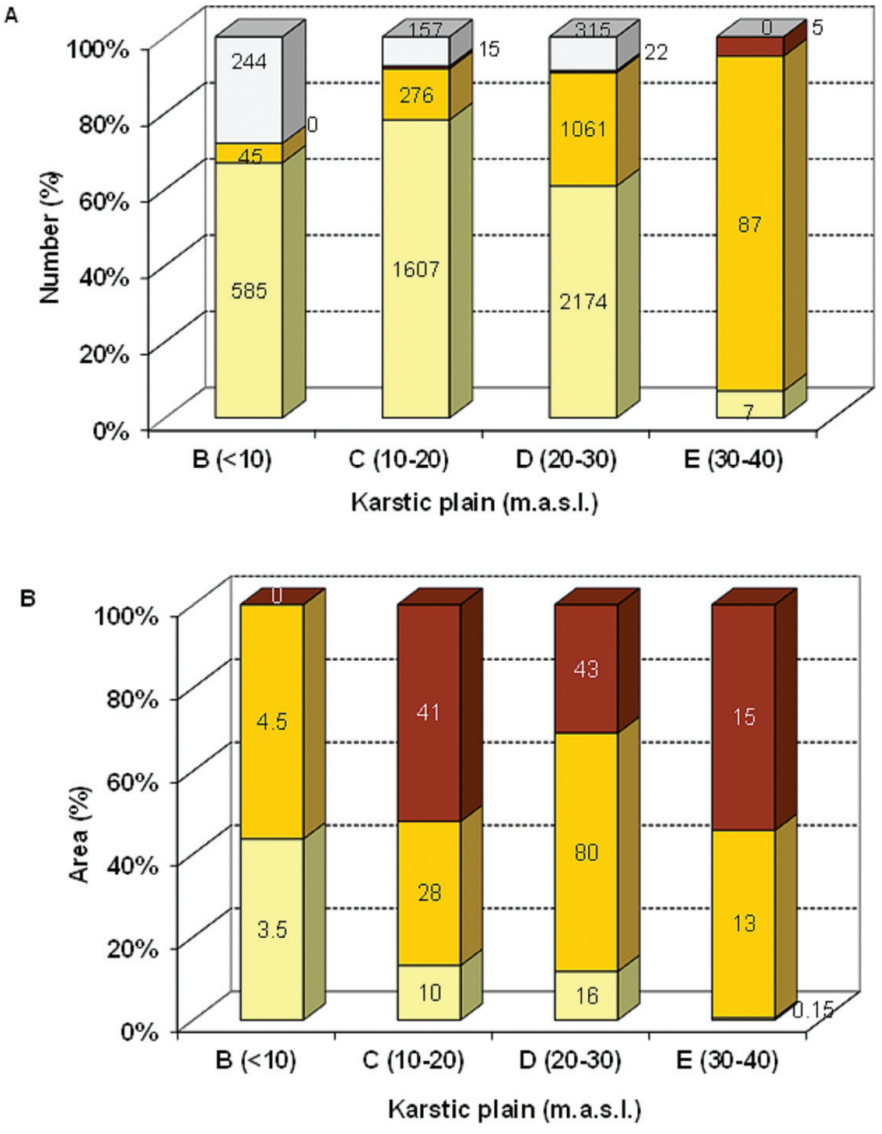

Figure 6. Distributions by number and total area of the various types of karst depressions in each of the indicated elevations ranges. The SEDUMA dataset of cenotes and caves does not include areas, so they are not included in part $B$.
In areas of the karst plateau lower than $10 \mathrm{~m}$ elevation, the dominant forms were dolines and smaller forms (cenotes, grottos and caves) (Fig. 6A); no poljes were found. This region, recently risen, is geologically composed of the Holocene to Pliocene portions of the Carrillo Puerto Formation (Lopez-Ramos, 1973; Lugo-Hubp and Garcia, 1999). Part of this plateau exhibits large areas of bare rock and a micro-relief of the limestone pavement type.

Elevation ranges $C$ and $D, 10-20 \mathrm{~m}$ and $20-30 \mathrm{~m}$ respectively, are similar, even in their lithological composition. They consist of Tertiary limestone from the Miocene-Pliocene part of the Carrillo Puerto Formation and the Oligocene, consisting of marl, lutites, and calcarenites. The lithology of some areas from the Eocene consists of fossiliferous crystalline limestone (Lopez-Ramos, 1973; Lugo-Hubp and Garcia, 1999; Villasuso and Méndez-Ramos, 2000). In terms of number, both these elevations are dominated by dissolution and collapse dolines, followed by uvalas, other features (cenotes and grottos) and finally, poljes (Fig. 6A). However, in terms of total area, dolines occupy the smallest area, while uvalas and poljes occupy the largest (Figure 6B).

The highest elevation range E, $30-40 \mathrm{~m}$, is geologically older; its lithology belongs to the Pisté Member of the Chichén Itzá Formation, consisting of fossiliferous crystalline limestone from the Middle Eocene (López-Ramos, 1973; Lugo-Hubp and Garcia, 1999; Villasuso and Mendez, 2000). It has been more exposed to the dissolution process, which has produced more evolved depressions such as uvalas and poljes. Only seven dolines have been recorded, but no features in the point database, although they could exist.

The typological map of depressions (Fig. 7A) shows the spatial arrangement of their different forms. The pattern of the ring of cenotes, formed by dolines, stands out. The map also shows the numerical dominance of dolines in eastern Yucatan, compared with the numbers of uvalas and poljes. The opposite case occurs in the south of the state, with fewer depressions and less area of both uvalas and poljes. 

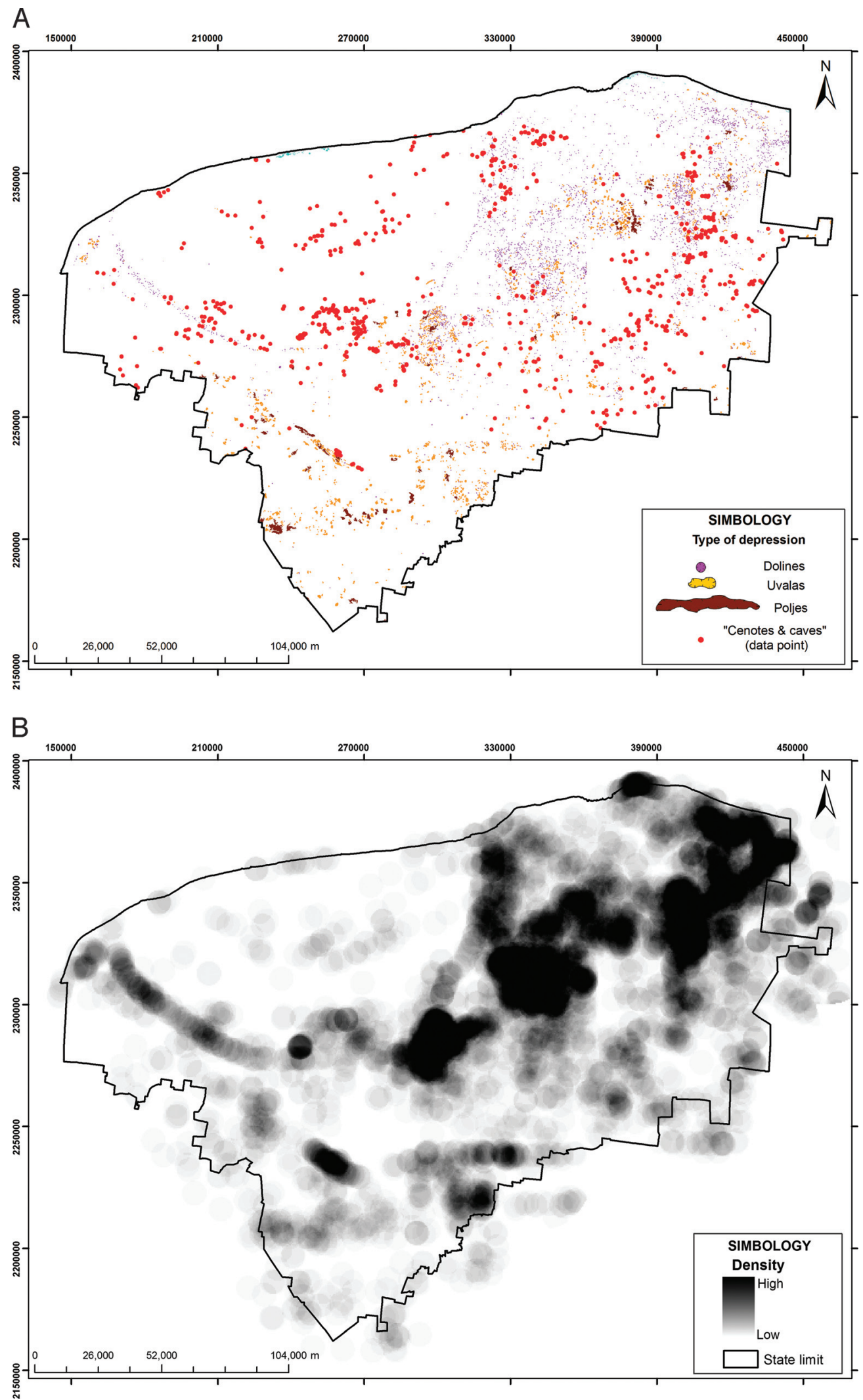

Figure 7. (A) Geographic distribution of types of karstic depressions identified in this study and the karst features in the SEDUMA dataset in the state of Yucatán. (B) Relative density of depressions calculated from the data in part A. The ring of cenotes and the fields of dolines in the eastern part of the state are conspicuous in the figure. 
Density analysis showed two main patterns of spatial distribution (Fig. 7Bb). As expected, the first is the ring of cenotes. The second is another important area in the east that can be called fields of dolines. These patterns of depression distribution coincide with the main structural lineaments reported in previous studies (Lugo-Hubp et al., 1992; Pope et al., 1993; Perry et al., 1995; Lugo-Hubp and Garcia, 1999). Thus the higher density of dolines is partially explained by the presence of the structures, as well as by the effect of weather.

\section{Discussion}

American and Caribbean countries have extensive karst areas, estimated at about $300,000 \mathrm{~km}^{2}$, of which the Yucatan Peninsula contains the largest area (Kueny and Day, 2002). These areas do not necessarily show the classic karst development proposed by Cvijic (1918), which is even considered obsolete (Fragoso-Servón et al., 2014). Bosák (2008) proposed a Caribbean model, pointing to certain characteristics shared by American and Caribbean countries that make them differ from the Dinaric karstic system. These characteristics of our study area include short exposure time, unstable mineralogy of shallowly-buried carbonate, fewer tectonic processes, a shallow phreatic zone, tropical and semi-arid environments, and mixing processes in the marine zone.

In general, it is recognized that depressions, particularly dolines, are the most characteristic features in karst systems. The circularity index can be interpreted as an indicator of the intensity of karstification or karst development. According to Brinkmann et al., (2008), more circular dolines indicate a more recent development of the karst landscape. The same authors found that the dolines in an area of Florida are more circular in sites lower than $30 \mathrm{~m}$ elevation and more complex and less circular at higher elevations. This is consistent with the patterns found in the karst plateaus of Yucatán; dolines dominate at elevations lower than $30 \mathrm{~m}$ that include the geologically younger Pleistocene area. In addition, $80 \%$ of the dolines are circular, with circularity index values equal to or lower than 1.04. In areas higher than $30 \mathrm{~m}$, the dominant depressions are the irregular in shape and more developed uvalas and poljes.

However, each karstic region has its particularities, and consequently, its own evolution dynamics (Kohler, 2001). This can be observed when comparing with the types of depressions in Quintana Roo (Fragoso-Servón et al., 2014), where, unlike Yucatán, uvalas are found in greater quantity at the various elevations, as well as poljes, which are located mainly at lower elevations, where the dissolution processes and the proximity to the phreatic zone favor development of these large sunken areas.

In this study, the depression density showed a pattern that goes from lower to higher density in the southwest to northeast direction (Fig. 7B). Significant alignments of karstic depressions can only be controlled by the existence of tectonic features (Siart et al., 2009), but secondary factors such as climate, mainly larger quantities and higher intensities of rain and warm temperatures, favorably influence karstic processes (Gracia, 1987; Gracia-Prieto, 1991), which appears as a similar pattern of low to high humidity (Delgado-Carranza et al., 2011).

In the case of the ring of cenotes, the structural factor is what defines this density pattern, since the ring is the surface expression of a buried crater and marks the boundary between non-fractured limestone inside the ring and fractured limestone outside it (Pope et al., 1993, 2001). Furthermore, the dissolution of limestone has been favored by the various sea-level fluctuations over time, as well as by the chemical processes produced by the mixing of freshwater and seawater (Back et al., 1986; Denizman and Randazzo, 2000).

In non-fractured limestone inside the ring, the density of karst depressions is low (Fig. 7B), with evidence of karst landforms of the limestone pavement type, with pans and some wide-mouth cenotes containing shallow water (LugoHubp et al., 1992); there are also Leptosols, specifically lithic and skeletal LPs in the notation of Bautista et al. (2011). The poor expression of the landforms and poor soil development are also the result of a semi-arid climate, with higher evapotranspiration rates, a rainfall period of less than three months, and no more than $150 \mathrm{~mm}$ of rainfall (Delgado-Carranza, 2010; Delgado-Carranza et al., 2011). These climatic conditions favored the formation of the laja, a local term for designating consolidated limestone. This area is described as the Chicxulub Sedimentary Basin by Perry et al. (1995, 2002).

Higher density values of karst depressions are found along a gradient to the southeast and east, forming a field of dolines (Fig. 7B) due to the concentration of circular depressions (Gracia-Prieto, 1991); these areas may be surface expressions of structural factors such as the fault zones of Chemax-Catoche (Pope et al., 1993). GraciaPrieto (1991) mentions that the fields of dolines are also related to the existence of secondary factors conducive to the development of these forms in specific areas of a karst massif. In the study area, climate is the secondary factor contributing to a high density of karst depressions, as the field of dolines coincides with areas with rainy seasons of five or even more than six months, as well as the presence of an additional wet period defined by low evapotranspiration (Delgado-Carranza, 2010; Delgado-Carranza et al., 2011). The presence of edaphic associations Leptosol/ Cambisol/Luvisol, that is, of soils with greater depth, also supports the evidence of a larger karstification process (Bautista et al., 2007, 2011). The fields of dolines are the manifestation of a highly developed epikarst with high permeability, and coincides with the area known as pockermarked terrain by Perry et al. (2002).

The karstic plateau with elevations $30-50 \mathrm{~m}$ (E in Fig. 6) emerged a longer time ago (Eocene) and also has rainy 
periods ranging from six to seven months with the presence of wet periods (Delgado-Carranza et al., 2011). Both factors, geological and climatic, may be behind the fact that in this area, though it has fewer depressions compared with area at lower elevations, the depressions occupy a larger area due to the dominance of more developed forms such as uvalas and poljes.

For the purpose of making karst-depression maps that include dolines and other small forms, satellite images and digital elevation models are insufficient inputs (Shofner et al., 2001; Gutiérrez-Santolalla et al., 2005; Siart et al., 2009). Thus Siart et al., (2009) indicated that an alternative methodological approach that combines inputs, processing, and spatial analysis, including the support and validation provided by fieldwork is needed to deal with this complexity. In this sense, the quantitative method proposed in this study allows us to obtain, relatively quickly, a first approximation of the spatial distribution patterns of the karst depressions when the study area is quite large, as in this study. It provides a way to semi-automate the typing of the depressions using a combination of inputs, mainly the semi-detailed topographic maps available in various Latin American countries (Bocco et al., 2001), as well as an inventory of karst features built by government agencies or speleologists (Ordóñez-Crespo and GarciaRodriguez, 2010).

Although this approach is useful and could be replicated in karstic geomorphological studies elsewhere in Latin America, it is important to consider that each region has its own particularities (Kohler, 2001) that could require an adaptation of the method. As reported by Fragoso-Servón et al. (2014), who applied the circularity index in Quintana Roo, they were able to identify only $62.1 \%$ of the depressions with certainty using the same parameters reported in this study. In that case, the authors used a discriminant analysis to improve the semi-automated criteria for classifying depressions.

\section{Conclusions}

Density maps of karst depressions have a wide range of applications. The different densities are indicative of the types of groundwater flow (Lindsey et al., 2010), and these characteristics should be included in models of groundwater flow (Kiraly, 2002; Parise et al., 2015a, b). In addition, density maps can also be used as precursors to tracer studies to identify preferential water flows to locate aquifer limits (Angel et al., 2004).

Lindsey et al. (2010) showed that there are high concentrations of nitrates and pesticides, mainly from agriculture, in places with high density of dolines. In this context, analysis of the depressions can help generate vulnerability assessments to delineate the boundaries of protection areas or for the use of water resources (Angel et al., 2004; Huang, 2007; Frausto and Ihl, 2008; Plan et al., 2009; Farfán González et al., 2009; Farfán et al. 2010; Molerio Leon and Parise, 2009; Lindsey et al., 2010). Depression-density maps are also useful in determining areas with hazard of subsidence and collapse (Angel et al., 2004; Gutiérrez-Santolalla et al., 2005; Ihl et al., 2007; Parise et al., 2008, 2015a; Galve et al., 2009; Simon et al., 2009; Parise and Lollino, 2011; Gutierrez et al., 2014).

The use of morphometric variables such as the index of circularity, area, and irregular shape allowed the semi-automated differentiation of karstic depressions, characterizing them into three main types, dolines, uvalas, and poljes. Dolines dominate in number, especially at elevations lower than $30 \mathrm{~m}$; furthermore, $80 \%$ of them tend to a circular shape, with circularity index values between 1 and 1.04. More complex forms (uvalas and poljes) dominate at elevations higher than $30 \mathrm{~m}$. The spatial patterns of karst depressions, such as the ring of cenotes and the field of dolines, depend on both structural and climatic factors. The use of inputs, such as topographic maps at 1:50000 scale and of inventories of karst features (caves, cenotes, grottos), is useful for analyzing extensive karst terrains, as in the study area. This method has a high degree of replicability, adaptability, and simplicity.

\section{ACKNOWLEDGMENTS}

The authors would like to thank Dr. E. Batllori for the technical support with the karstic depressions database. We also thank the Dirección General de Asuntos del Personal Académico (DGAPA) de la Universidad Nacional Autónoma de México (UNAM) for their financial support to the project PAPIIT IN223110-3. Yameli Aguilar thanks the CONACYT for the Ph.D. fellowship. Francisco Bautista thanks DGAPA-UNAM the financial support for the sabbatical stay in CEBAS-CSIC in Spain.

\section{REFERENCES}

Angel, J.C., Nelson, D.O., and Panno, S.V., 2004, Comparison of a new GIS-based technique and a manual method for determining sinkhole density: An example from Illinois' sinkhole plain: Journal of Cave and Karst Studies, v. 66, p. 9-17.

Back, W., Hanshaw, B.B., Herman, J.S., and Van Driel, J.N., 1986, Differential dissolution of a Pleistocene reef in the ground-water mixing zone of coastal Yucatan, Mexico: Geology, v. 14, no. 2, p. 137-140, doi: 10.1130/0091-7613(1986)14<137:DDOAPR >2.0.CO;2.

Basso, A., Bruno, E., Parise, M., and Pepe, M., 2013, Morphometric analysis of sinkholes in a karst coastal area of southern Apulia (Italy): Environmental Earth Sciences, v. 70, p. 2545-2559, doi: 10.1007/ s12665-013-2297-z.

Bautista, F., Aguilar, Y., Rivas, H., and Páez, R., 2007, Los suelos del estado de Yucatán, in Sánchez-Monedero, M., and Cabañas, D., eds., Importancia del Binomio Suelo Materia Orgánica en el Desarrollo Sostenible: Murcia, Spain, Consejo Superior de Investigaciones Científicas, Agencia Española de Cooperación Internacional, p. $11-42$.

Bautista, F., Batllori-Sampedro, E., Palacio-Aponte, G., Ortiz-Pérez, M., and Castillo-González, M., 2005, Integración del conocimiento actual sobre los paisajes geomorfológicos de la Península de Yucatán, in 
Bautista Zúñiga, F., and Palacio, Á.G., eds., Caracterización y Manejo de los Suelos de la Península de Yucatán: Implicaciones Agropecuarias, Forestales y Ambientales: Universidad Autónoma de Campeche, Universidad Autónoma de Yucatán, p. 33-58.

Bautista-Zúñiga, F., Batllori-Sampedro, E., Ortiz-Pérez, M.A., PalacioAponte, G., and Castillo-González, M., 2003, Geoformas, agua y suelo en la Península de Yucatán, in Colunga-GarcíaMarín, P., and LarquéSaavedra, A., eds., Naturaleza y Sociedad en el Área Maya. Pasado, Presente y Futuro: Academia Mexicana de Ciencias y Centro de Investigación Científica de Yucatán, p. 21-35.

Bautista, F., Palacio-Aponte, G., Quintana, P., and Zinck, A.J., 2011, Spatial distribution and development of soils in tropical karst areas from Peninsula of Yucatan, Mexico: Geomorphology, v. 135, p. 308-321, doi:10.1016/j.geomorph.2011.02.014.

Bocco, G., Mendoza, M.E., and Velásquez, A., 2001, Remote sensing and GIS-based regional geomorphological mapping-a tool for land use planning in developing countries: Geomorphology, v. 39, p. 211-219, doi:10.1016/S0169-555X(01)00027-7.

Bonor Villajero, J.L., and Sánchez Pinto, I., 1991, Cavernas del municipio de Oxkutzcab, Yucatán, México: Nuevas aportaciones: Revista Mayab, n. 7, p. 36-52.

Bosák, P., 2008, Karst processes and time: Geologos, v. 14, p. 19-36.

Brinkmann, R., Parise, M., and Dye, D., 2008, Sinkhole distribution in a rapidly developing urban environment: Hillsborough County, Tampa Bay area, Florida: Engineering Geology, v. 99, p. 169-184. doi:10.1016/ j.enggeo.2007.11.020

Bruno, E., Calcaterra, D., and Parise, M., 2008, Development and morphometry of sinkholes in coastal plains of Apulia, southern Italy. Preliminary sinkhole susceptibility assessment: Engineering Geology, v. 99, p. 198-209. doi: 10.1016/j.enggeo.2007.11.017.

Cole, L. J., 1910, The caverns and people of Northern Yucatan: Bulletin of the American Geographical Society, v. 42, p. 321-336. http://www. jstor.org/stable/199038?seq $=2$ (accessed October 2010).

Cvijic, M.J., 1918, Hydrographie souterraine et évolution morphologique du Karst: Recueil des Travaux de l'Institut de Géographie Alpine, v. 6, p. 375-426. doi:10.3406/rga.1918.4727. http://www.persee.fr/ web/revues/home/prescript/article/rga_0249-6178_1918_num_6_4_ 4727 (accessed April 2010).

Delgado-Carranza, C., 2010, Zonificación agroecológica del estado de Yucatán con base en índices agroclimáticos y calidad agrícola del agua subterránea (Ph.D. thesis): Centro de Investigación Científica de Yucatán, Mérida, Yucatán, México, 162 p.

Delgado-Carranza, C., Bautista, F., Orellana-Lanza, R., and ReyesHernández, H., 2011, Classification and agroclimatic zoning using the relationship between precipitation and evapotranspiration in the state of Yucatán, Mexico: Investigaciones Geográficas, Boletín del Instituto de Geografía, UNAM, no. 75, p. 51-60. doi:10.14350/ rig. 29795.

Delle Rose, M., and Parise, M., 2002, Karst subsidence in south-central Apulia Italy: International Journal of Speleology, v. 31, p. 181-199. doi: 10.5038/1827-806X.31.1.11.

Denizman, C., 2003, Morphometric and spatial distribution parameters of karstic depressions, Lower Suwannee River Basin, Florida: Journal of Cave and Karst Studies, v. 65, p. 29-35.

Denizman, C., and Randazzo, A.F., 2000, Post-Miocene subtropical karst evolution, lower Suwannee River basin, Florida: Geological Society of American Bulletin, v. 112, p. 1804-1813. doi:10.1130/0016-7606(2000) $112<1804:$ PMSKEL $>2.0$. CO 2 .

Farfán, H., Dias, C., Parise, M., and Aldana, C., 2010, Scenarios of groundwater pollution in a karst watershed: A case study in the Pinar del Rio province at Cuba, in Carrasco, F., LaMoreaux, J.W., Durán, J.J., and Andreo, B., eds., Advances in Research in Karst Media: Heidelberg, Springer, Environmental Earth Sciences Series 1, p. 287-292. doi: 10.1007/978-3-642-12486-0_44.

Farfán González, H., Díaz Guanche, C., Parise, M., Aldana Vilas, C., y Corvea Porras, J.L., 2009, Inventario y caracterización de los escenarios de peligros a la contaminación de las aguas en la Cuenca del Arroyo de Santo Tomás, Viñales, Cuba: Mapping, no. 135, p. 66-70.

Farfán González, H., Díaz Guanche, C., and Ramírez, R., 2010, Algunas consideraciones sobre el desarrollo y distribución de las dolinas en el Parque Nacional Viñales, Pinar del Río, Cuba: Mapping, no. 139, p. $46-50$.

Finch, W. A., 1965, The Karst Landscape of Yucatan: Washington, D.C., National Research Council, 180 p.
Florea, L., 2005, Using state-wide GIS data to identify the coincidence between sinkholes and geologic structure: Journal of Cave and Karst Studies, v. 67, p. 120-124.

Fragoso-Servón, P., Bautista, F., Frausto, O., and Pereira, A., 2014, Caracterización de las depresiones kársticas (forma, tamaño y densidad) a escala 1:50000 y sus tipos de inundación en el Estado de Quintana Roo, México: Revista Mexicana de Ciencias Geológicas, v. 31, no. 1, p. $127-137$.

Fragoso-Servón, P., Pereira, A., Frausto, O., Bautista, F., 2015. Geodiversity of a tropical karst zone in south-east Mexico, in Andreo, B., Carrasco, F., Durán, J.J., Jiménez, P., and LaMoreaux J.W., eds., Hydrogeological and Environmental Investigations in Karst Systems: Heidelberg, Springer, vol 1, p. 609-618. doi: 10.1007/978-3-64217435-3_68.

Frausto, O., and Ihl, T., 2008, Mapa de formas exokársticas del norte de Quintana Roo a escala 1:50000, in Gutiérrez-Aguirre, M.A., and Cervantes-Martínez, A., eds., Estudio Geohidrológico del Norte de Quintana Roo, México: Universidad de Quintana Roo, p. 45-58:

Galve, J.P., Gutiérrez, F., Remondo, J., Bonachea, J., Lucha, P., and Cendrero, A., 2009, Evaluating and comparing methods of sinkhole susceptibility mapping in the Ebro Valley evaporite karst (NE Spain): Geomorphology, v. 111, p. 160-172. doi:10.1016/j.geomorph.2009. 04.017 .

García, E., 2004, Modificaciones al Sistema de Clasificación Climática de Köppen, fifth edition: Universidad Nacional Autónoma de México, Instituto de Geografía, Serie Libros 6, 90 p.

Gao, Yongli, 2008, Spatial operations in a GIS-based karst feature database: Environmental Geology, v. 54, p. 1017-1027. doi: 10.1007/ s00254-007-0896-2.

Gao, Yongli, and Zhou, Wanfang, 2008, Advances and challenges of GIS and DBMS applications in karst: Environmental Geology, v. 54, p. 901-904. doi: 10.1007/s00254-007-0894-4.

Goeppert, N., Goldscheider, N., and Scholz, H., 2011, Karst geomorphology of carbonatic conglomerates in the Folded Molasse zone of the Northern Alps (Austria/Germany): Geomorphology, v. 130, p. 289298. doi:10.1016/j.geomorph.2011.04.011.

Gracia, F.J., 1987, Controles morfométricos de los campos de dolinas en el sector central de la Cordillera Ibérica: Cuaternario y Geomorfología, v. 1 , p. $119-134$

Gracia-Prieto, F. J., 1991, Criterios de clasificación morfométrica de campos de dolinas: Cuaternario y Geomorfología, v. 5, p. 65-76.

Gutiérrez, F., Guerrero, J., and Lucha, P., 2008, A genetic classification of sinkholes illustrated from evaporite paleokarst exposures in Spain: Environmental Geology, v. 53, p. 993-1006. doi: 10.1007/s00254-0070727-5.

Gutierrez, F., Parise, M., De Waele, J., and Jourde, H., 2014, A review on natural and human-induced geohazards and impacts in karst: Earth Science Reviews, v. 138, p. 61-88. doi: 10.1016/j.earscirev.2014.08.002.

Gutiérrez-Santolalla, F., Gutiérrez-Elorza, M., Marín, C., Desir, G., and Maldonado, C., 2005, Spatial distribution, morphometry and activity of La Puebla de Alfindén sinkhole field in the Ebro river valley (NE Spain): Applied aspects for hazard zonation: Environmental Geology, v. 48 , p. $360-369$. doi: $10.1007 / \mathrm{s} 00254-005-1280-8$.

Huang, H.H., 2007, Geomorphologic investigations on karst terrain: a GIS-assisted case study on the island of Barbados (M.S. thesis): Montréal, Québec, McGill University, 108 p.

Hung, L.Q., Dinh, N.Q., Batelaan, O., Tam, V.T., and Lagrou, D., 2002, Remote sensing and GIS-based analysis of cave development in the Suoimuoi catchment (Son La - NW Vietnam): Journal of Cave and Karst Studies, v. 64, p. 23-33.

Ihl, T., Frausto Martínez, O., Rojas López, J., Giese, S., Goldacker, S., Bautista Zúñiga, F., and Bocco Verdinelli, G., 2007, Identification of geodisasters in the state of Yucatan, Mexico: Neues Jahrbuch für Geologie und Paläontologie Abhandlungen, v. 246, p. 299-311. doi: 10.1127/ 0077-7749/2007/0246-0299.

INEGI (Instituto Nacional de Estadística, Geografía e Informática), 1999, Conjunto de datos vectoriales escala 1:50,000, 58 files, INEGI, México.

Jennings, J.N., 1997, Cave and karst terminology: Australian Speleological Federation Inc. http://home.mira.net/ gnb/caving/papers/jj-cakt.html [accessed November, 2009].

Kiraly, L., 2002, Karstification and groundwater flow, in Gabrovšek, F., eds., Evolution of Karst: from Prekarst to Cessation: Postojna-Ljubljana, Zalozba ZRC, pp. 155-190. 
Kohler, H.C., 2001, Geomorfología cárstica, in Teixeira-Guerra, A.J., and Baptista da Cunha, S., eds., Geomorfología, uma Atualização de Bases e Conceitos: Rio de Janeiro, Bertrand Brasil, p. 309-334.

Kueny, J.A., and Day, M.J., 2002, Designation of protected karstlands in Central America: A regional assessment: Journal of Cave and Karst Studies, v. 64, p. 165-174.

Lindsey, B.D., Katz, B.G., Berndt, M.P., Ardis, A.F., and Skach, K.A., 2010, Relations between sinkhole density and anthropogenic contaminants in selected carbonate aquifers in the Eastern United States: Environmental Earth Sciences, v. 60, no. 5, p. 1073-1090. doi: 10.1007/ s12665-009-0252-9.

López-Ramos, E., 1973, Estudio geológico de la Península de Yucatán: Boletín Asociación Mexicana de Geólogos Petroleros, v. 25, p. 23-76.

Lugo-Hubp, J., Aceves-Quesada, J.F., and Espinasa-Pereña, R., 1992, Rasgos geomorfológicos mayores de la Península de Yucatán: Revista Universidad Autónoma de México Instituto de Geología, v. 10, no. 2, p. $143-150$.

Lugo-Hubp, J.I., and García, M.T., 1999, El relieve de la península de Yucatán, in García de Fuentes, A., Córdoba, J., and Ponce, Ch., eds., Atlas de Procesos Territoriales del Estado de Yucatán, Facultad de Arquitectura, Universidad Autónoma de Yucatán, México, p. $155-162$.

Lyew-Ayee, P., Viles, H.A., and Tucker, G.E., 2007, The use of GIS-based digital morphometric techniques in the study of cockpit karst: Earth Surface Processes and Landforms, v. 32, p. 165-179. doi: 10.1002/ esp.1399.

Marín-Stillman, L.E., Pachecho-Ávila, J.G., and Méndez-Ramos, R., 2004, Hidrogeología de la Península de Yucatán, in Jiménez, B., and Marín, L., eds., El Agua en México, Vista desde la Academia: México, D.F., Academia Mexicana de Ciencias, p. 159-176.

Molerio León, L., and Parise, M., 2009, Managing environmental problems in Cuban karstic aquifers: Environmental Geology, v. 58, p. 275-283. doi: 10.1007/s00254-008-1612-6.

NASA/JPL, 2000, Shaded Relief with Height as Color, Yucatan Peninsula, Mexico, from Mission Shuttle Radar Topography Mission (SRTM), resolution about 30 meters or 98 feet, http://photojournal.jpl.nasa. gov/catalog/PIA03379 (accessed June, 2008).

Ordoñez-Crespo, I., and García-Rodríguez, M., 2010, Formas kársticas comunes de los cenotes del estado de Quintana Roo (México) : $\mathrm{M}+\mathrm{A}$, Revista Electrónica de Medio Ambiente, v. 9, p. 15-35. http://revistas. ucm.es/index.php/MARE/article/view/MARE1010220015A [accessed July 2012].

Parise, M., Closson, D., Gutiérrez, F., and Stevanović, Z., 2015a, Anticipating and managing engineering problems in the complex karst environment: Environmental Earth Sciences, 13 p. doi:10.1007/s12665015-4647-5.

Parise, M., De Waele, J. and Gutierrez, F., 2008, Engineering and environmental problems in karst - An introduction: Engineering Geology, v. 99, p. 91-94. doi: 10.1016/j.enggeo.2007.11.009.

Parise, M., and Lollino, P., 2011, A preliminary analysis of failure mechanisms in karst and manmade underground caves in Southern Italy: Geomorphology, v. 134, p. 132-143. doi: 10.1016/j.geomorph.2011.06.008.

Parise, M., Ravbar, N., Živanović, V., Mikszewski, A., Kresic, N., MádlSzőnyi, J., and Kukurić N., 2015b, Hazards in karst and managing water resources quality, in Stevanović, Z., ed., Karst Aquifers - Characterization and Engineering: Cham, Switzerland, Springer, Professional Practice in Earth Sciences series, p. 601-687. doi: 10.1007/978-3-31912850-4_17.
Pavlopoulos, K., Evelpidou, N, and Vassilopoulos, A., 2009, Karstic environments, in Mapping Geomorphological Environments: Heidelberg, Springer-Verlag, p. 135-150. doi: 10.1007/978-3-642-01950-0.

Pepe, M., and Parise, M., 2014, Structural control on development of karst landscape in the Salento Peninsula (Apulia, SE Italy): Acta Carsologica, v. 43, p. 101-114. doi: 10.3986/ac.v43i1.643.

Perry, E., Marin, L., McClain, J., and Velazquez, G., 1995, Ring of Cenotes (sinkholes), northwest Yucatan, Mexico: Its hydrogeologic characteristics and possible association with the Chicxulub impact crater: Geology, v. 23, p. 17-20. doi: 10.1130/0091-7613(1995)023<0017: ROCSNY > 2.3.CO;2.

Perry, E., Velasquez-Oliman, G., and Marin, L., 2002, The hydrogeochemistry of the karst aquifer system of the Northern Yucatan Peninsula, Mexico: International Geology Review, v. 44, p. 191-221. doi: $10.2747 /$ 0020-6814.44.3.191.

Plan, L., Decker, K., Faber, R., Wagreich, M., and Grasemann, B., 2009, Karst morphology and groundwater vulnerability of high alpine karst plateaus: Environmental Geology, v. 58, p. 285-297. doi: 10.1007/ s00254-008-1605-5.

Pope, K.O., Ocampo, A.C., and Duller, C.E., 1993, Surficial geology of the Chicxulub impact crater, Yucatan, Mexico: Earth, Moon, and Planets, v. 63, p. 93-104. doi: 10.1007/BF00575099.

Pope, K.O., Rejmankova, E., and Paris, J.F., 2001, Spaceborne imaging radar-C (SIR-C) observations of groundwater discharge and wetlands associated with the Chicxulub impact crater, northwestern Yucatan Peninsula, Mexico: Geological Society of America Bulletin, v. 113, p. 403-416. doi: 10.1130/0016-7606(2001)113<0403:SIRCSC >2.0.CO;2.

Shofner, G.A., Mills, H.H., and Duke, J.E., 2001, A simple map index of karstification and its relationship to sinkhole and cave distribution in Tennessee: Journal of Cave and Karst Studies, v. 63, p. 67-75.

Siart, C., Bubanzer, O., and Eitel, B., 2009, Combining digital elevation data (SRTM/ASTER), high resolution satellite imagery (Quickbird) and GIS for geomorphological mapping: A multi-component case study on Mediterranean karst in central Crete: Geomorphology, v. 112, p. 106-121. doi:10.1016/j.geomorph.2009.05.010.

Simón, J.L., Soriano, M.A., Pocoví Juan, A., Arlegui Crespo, L.E., Casas Sáinz, A.M., Liesa Carrera, C.L., Luzón, A., Pérez García, A., Pueyo Anchuela, O., Pueyo Morer, E.L., Mochales, T., Gracia-Abadías, F.J., and Ansón, D., 2009, Riesgo de subsidencia kárstica en áreas urbanas: El caso de Zaragoza: Enseñanza de las Ciencias de la Tierra, v. 17, p. $303-315$.

Szukalski, B.W., 2002, Introduction to cave and karst GIS: Journal of Cave and Karst Studies, v. 64, p. 3.

Villasuso, M.J., and Méndez-Ramos, R., 2000, A conceptual model of the aquifer of the Yucatan Peninsula, in Lutz, W., Prieto, L., and Sanderson, W., eds., Population, Development, and Environment on the Yucatán Peninsula: From Ancient Maya to 2030: Laxenburg, Austria, International Institute for Applied Systems Analysis, p. 120-139.

Waltham, T., Bell, F., and Culshaw, M., 2005, Sinkholes and Subsidence: Karst and Cavernous Rocks in Engineering and Construction: Berlin, Springer, $382 \mathrm{p}$.

White, E.L., and White, W.B., 1979, Quantitative morphology of landforms in carbonate rock basins in the Appalachian Highlands: Geological Society of American Bulletin, v. 90, p. 385-396. doi: 10.1130/00167606(1979)90<385:QMOLIC $>2.0$. CO;2.

Williams, P.W., 1972, Morphometric analysis of polygonal karst in New Guinea: Geological Society of American Bulletin, v. 83, p. 761-796. doi: 10.1130/0016-7606(1972)83[761:MAOPKI]2.0.CO;2. 